\title{
Investigating the nature and fate of mining-related historical contaminations with geochemical and microbiological tools in the transboundary Drava River Floodplain
}

\author{
PÉTER SZABÓ ${ }^{1}$, GYOZO JORDAN ${ }^{2}$, TAMÁS KOCSIS ${ }^{2}$,
} LEVENTE KARDOS ${ }^{2}$, ROBERT ŠAJN ${ }^{3}$ AND JASMINKA ALIJAGIĆ 3

${ }^{1}$ Eötvös Loránd University

${ }^{2}$ Hungarian University of Agriculture and Life Sciences

${ }^{3}$ Geological Survey of Slovenia

Presenting Author: szbpeet@gmail.com

The transboundary catchment of the $700 \mathrm{~km}$ long Drava River has been an important area for industrial activities since historical times. As a result of mining and smelting, along with the associated industry, the sediments and soils in the extensive floodplains are characterized by elevated concentration of potentially toxic elements (PTEs; As, $\mathrm{Cu}, \mathrm{Zn}, \mathrm{Cd}, \mathrm{Pb}$ ), exceeding the environmental quality standard threshold values [1]. At the same time, the floodplains are sensitive receptors of upstream contaminations, endangering agricultural food safety and local ecosystems.

Fluvial sediment and soil samples from different depths (0-10 $\mathrm{cm}$ and $40-50 \mathrm{~cm}$ ) were collected in the alluvial plain and river terrace areas which were subjected to chemical analyses in order to assess the total and mobile (water leachable) chemical element contents, together with soil chemical parameters such as $\mathrm{pH}$, electric conductivity and carbonate content.

In order to understand the effect of the contamination on soil microbes, the bulk microbial activity, the rate of catabolic and anabolic processes, the mobility of phosphorus, microbial diversity and the number of cells and fungi were determined.

Data was modelled with descriptive statistics, univariate, bivariate and multivariate analyses, complemented by spatial visualisation using GIS technology. The obtained results show that there is a significant difference between alluvial plain and river terrace sediment contamination, while soil depth (topsoil vs subsoil) seems to be an important factor for soil microbiological parameters. The microbiota can adapt to the changes in toxic elements concentrations, or at least a few species can highly tolerate it, so the overall cell number does not decrease, only the diversity or the proportion of some species. Results can help to assess the distribution and the mobility of contamination, highlighting hot spots of endangered areas on the Drava River floodplain.

This research contributed to a Slovenian-Hungarian OTKA project (SNN OTKA 118101). The project was co-funded by European Union Fund, ERDF, IPA, ENI (DTP2-093-2.1 SIMONA).

[1] Šajn, Halamić, Peh, Galović \& Alijagić (2011), Journal of Geochemical Exploration 110, 278-289. 